\title{
A Juggling Act: Supervisor/Candidate Partnership in a Doctoral Thesis by Publication
}

\author{
Rohan Nethsinghe \\ RMIT University, \\ Bundoora, Victoria, Australia
}

Rohan.nethsinghe@rmit.edu.au

\author{
Jane Southcott \\ Monash University, \\ Clayton, Victoria, Australia
}

Jane.Southcott@monash.edu

\begin{abstract}
Increasingly doctoral candidates are attempting to complete a thesis by publication. This format varies between universities but there are common issues particularly in terms of progression, planning and timing. There are both advantages and difficulties involved in undertaking a thesis in this format. Our discussion of the supervisor/candidate partnership is framed within the requirements of a tight journal publishing agenda. Different universities have different requirements about the number of published papers to be included, the extent of candidate's contribution as sole or joint author, the framing of the research as a unified thesis, presentation, and examination. The decision to attempt a thesis by publication must be taken early and data collection may need to be completed early. Articles then need to be written, polished, submitted, reviewed, revised and, hopefully, accepted. The thesis by publication is a juggling act between maintaining coherence and focusing on publishable segments. It is also a dialogue between supervisor and candidate involving the resolution of sometimes conflicting demands. Employing Cognitive Apprenticeship theory we present a shared autophenomenography that chronicles our doctoral journey that led to a successful thesis by publication. The findings are discussed under thematic headings: Logistics, Cognitive Apprenticeship in Action, and Building Trust.
\end{abstract}

Keywords: Doctoral supervision, thesis with publication, cognitive apprenticeship, mentoring, building trust, shared autophenomenography.

\section{Introduction}

Over the past decade there has been increasing interest in the "processes, educational strategies, outcomes, and cultural and methodological dimensions of postgraduate supervision ... [and] a growing number of potential and neophyte research students and supervisors who seek information about the nature of supervision" (Holbrook \& Johnston, 1999, p. 3). There is international

Material published as part of this publication, either on-line or in print, is copyrighted by the Informing Science Institute. Permission to make digital or paper copy of part or all of these works for personal or classroom use is granted without fee provided that the copies are not made or distributed for profit or commercial advantage AND that copies 1) bear this notice in full and 2) give the full citation on the first page. It is permissible to abstract these works so long as credit is given. To copy in all other cases or to republish or to post on a server or to redistribute to lists requires specific permission and payment of a fee. Contact Publisher@InformingScience.org to request redistribution permission. demand for a sustainable supply of researchers and a "throughput of productive doctoral students is vital to the health of academic disciplines" (Park, 2007b, p. 13). Pursuing a doctorate by publication is advocated in a number of disciplines as an effective alternative to the 'traditional' $\mathrm{PhD}$ that allows candidates the "opportunity for academic, professional, and personal development" (Davies \& Rolfe, 2009, p. 593). It is im- 
perative for doctoral candidates to build a track record of publication to enhance their employment potential (Jackson, 2013; Knight \& Steinbach, 2008; Paré, 2010; Robins \& Kanowski, 2008). This article explores the logistics and processes involved in undertaking a thesis by publication in the field of music education at Monash University, Australia by the first author (Rohan) under the supervision of the second (Jane). We have used the model of Cognitive Apprenticeship (Collins, Brown, \& Newman, 1989) to scaffold our phenomenological research and focused on the nature of the supervisor/supervisee relationship.

Doctoral supervision is becoming increasingly complex and challenging (Melin Emilsson \& Johnsson, 2007). There has been an "explosion of interest and innovation in higher degree research processes and practices" (Aitchison, Kamler, \& Lee, 2010, p. 1) and doctoral provision has been the subject of "increasing scrutiny across the higher education sector" (Lee, 2009, p. 641). The route to attaining a doctoral qualification is rapidly metamorphosing into diverse forms and pathways (Park, 2007a). Undertaking a doctorate by publication is not new but was first adopted in the UK in 1966 by the University of Cambridge (Wilson, 2002). There has been a rapid growth in demand for PhDs by publication in the UK that may be understood as a response to institutional pressure for research productivity ('publish or perish') (Jackson, 2013). This pressure is also felt in Australia and it could be expected that the PhD by publication would be a more popular option, but the vagueness and inconsistency of university guidelines makes selecting this option problematic. Concerning the lack of clarity, Bradley (2009, p. 336) notes "a need for more harmonization of policy and guidelines amongst institutions". This coupled with a relative paucity of supervisory experience in completing $\mathrm{PhDs}$ by this method "means the process continues to be treated with considerable caution in Australia (Jackson, 2013, p. 356).

The supervision of research degrees per se is of considerable interest (Clegg \& Gall, 1998; Melin Emilsson \& Johnsson, 2007). Postgraduate research itself is a complex and constantly changing process and for some time "researchers, practitioners, and professionals have attempted to understand and make sense of the world ... with research supervision noted as particularly challenging" (Grant, Hackney \& Edgar, 2014, p. 43). There is a "need to explore issues of quality in postgraduate supervision in education" (Johnson, 1999, p. 18) but it is widely acknowledged that successful candidature relies on the supervisor-candidate relationship (Holbrook \& Johnston, 1999; Johnston, 1999) in which trust is central (Melin Emilsson \& Johnsson, 2007). A supervisor should have the qualities of a mentor who supports and encourages candidates to develop their skills in every aspect of academic endeavour. A mentor should be consistent, trusting and trustworthy, fair, and expert (Erdem \& Aytemur 2008; Wadee, Keane, Dietz, \& Hay, 2010). Aspirationally, Sambunjak, Straus, \& Marusic (2009) identify desired characteristics of mentors within three dimensions - the personal, the relational and the professional. Personal characteristics include understanding, patience, honesty, responsiveness, trustworthiness, reliability, active listening, and being a motivator. Bibby (1999) considers honesty as a requisite of the maintenance of trust. Relational characteristics include accessibility, commitment to the collegial relationship, and a determination to assist mentees achieve to their highest level (Sambunjak et al., 2009). Professionalism implies that the mentor should be senior, well respected, knowledgeable, and experienced. The mentoring relationship evolves over time with honesty, trust, mutual respect, open communication and confidentiality (Sambunjak et al., 2009). A strong mentoring relationship builds a safe environment for intellectual exploration both of self as researcher and of the issues being researched. It is part of the role of the mentor to "provide emotional support ... such as developing, encouraging, and maturing their protégés' self-esteem and self-motivation" (Erdem \& Aytemur, 2008, p. 56).

Trust is considered the core component in the mentor/mentee relationship. Trust can be defined as "the willingness of a party to be vulnerable to the actions of another party based on the expectation that the other will perform a particular action important to the trustor, irrespective of the abil- 
ity to monitor or control that other party" (Mayer, Davis, \& Schoorman, 1995, p. 712). Elements of trust include ability, benevolence, and integrity. These are all important in varying degrees and independent of each other (Mayer et al., 1995). Initially a mentor may trust a protégé because of a perception of these qualities (Leck \& Orser, 2013) but over time a more equitable working process should be built in which protégés feel they could take initiative and participate in decision making. Trust by both partners is essential and is initially bestowed then confirmed and extended. Trust incorporates the concept of benevolence that includes the determination to do good and implies attachment. Corollary to this is the "relationship between integrity and trust [that] involves the trustor's perception that the trustee adheres to a set of principles that the trustor finds acceptable" (Mayer et al., 1995, p. 719). Attaining trust involves risk in that the protagonists must be willing to be vulnerable and open.

Postgraduate research has been identified as a process of learning in context that possesses qualities of master-apprenticeship training "where the established 'master' inducts the new apprentice into the 'mysteries' of the craft" (Yeatman, 1995, p. 9). Our personal experience of this doctoral candidature (as supervisor and candidate) aligns in some ways with the master-apprenticeship model. Paré (2010) asserts that the $\mathrm{PhD}$ by publication requires supervisors who are already expert and successful in "the genres of the profession ... and who are also able to induct students into their discipline's discourse practices" (p. 36). Erdem and Aytemur (2008) point out that "as a vital element of academic culture, mentoring is a one-to-one learning relationship between senior and junior academics based on dialogue and provision of a role model" (p. 56). It is important to mention that prior to engaging in academia we were both trained as musicians. Traditionally instrumental music education adopts a master-apprenticeship model, so the positions of both master and apprentice were very familiar to both supervisor and supervisee. Both Rohan and Jane recognise that the master holds knowledge, skills and the expertise that is shared with the apprentice, in this case as part of a doctoral candidature (Wadee et al., 2010). The building of a mentoring relationship occurs within a co-constructed learning space that permits uncertainty and exploration, provides safety and a collaborative ethos, allows difference and openness, and is in some ways open-ended (Andreotti, 2011).

\section{Theoretical Underpinning: Cognitive Apprenticeship}

We employ Cognitive Apprenticeship theory (Collins et al., 1989) as the most appropriate theoretical underpinning to understand the teaching and learning experiences of both participants. Developed on constructivist approaches to learning and supported by situated cognition theory and the theory of modeling (Bandura, 1997), the cognitive apprenticeship model (Collins et al., 1989) is a combination of two terms from different areas. Cognition is understood as the process of knowledge acquisition and apprenticeship is the interaction between an expert and a novice learner, in which the expert assists the learner to become a master of skills through "modeling, scaffolding, fading and coaching" (Collins, Brown, \& Holum, 1991, p. 2). Collins et al. (1991) explain fading as "the notion of slowly removing the support, giving the apprentice more and more responsibility" (p. 2). Simply put, cognitive apprenticeship theorises the process of learning by doing having emerged from the study of what occurs when people work and study simultaneously (Collins et al., 1991). In a higher degree research training program the candidate works on a research project while learning the process of becoming a researcher (doing research and disseminating results) from an experienced research supervisor. Explaining the significance of cognitive apprenticeship Collins et al. (1991) advise that in this approach "one needs to deliberately bring the thinking to the surface, to make it visible, whether it's in reading, writing, [or] problem solving", simply put "the teacher's thinking must be made visible to the student and the student's thinking must be made visible to the teacher" (p. 3). To value thinking it is essential to unpack and identify just what it entails (Ritchhart, Church, \& Morrison, 2011). We believe that transparent discussion of thinking and writing is essential to achieving a successful doctoral completion. 
Park (2007b, p. 29) asserts that supervision should become "more transparent and more accountable". We have used Cognitive Apprenticeship theory to scaffold our thinking.

According to Collins et al. (1989), there are different types of knowledge required for an expert to retain expertise. They are knowledge of the domain (concepts, facts, and procedures), heuristic strategies (effective techniques and approaches for accomplishing tasks), and control and learning strategies. Instructional strategies encompassed in the notion of cognitive apprenticeship (Collins et al., 1989) are:

Modelling in which an expert carries out a task while the student observes and builds a conceptual model of the requisite processes;

Coaching where the expert observes the student's performance, offers hints, and suggests new tasks;

Scaffolding whereby the teacher helps the student accomplish a task;

Articulation when the student can articulate their knowledge, reasoning, or problemsolving processes in a domain;

Reflection that enables students to compare their own problem-solving processes with those of an expert, peer, and a growing of an internal cognitive model of expertise;

Exploration where the teacher sets general goals encouraging students to focus on particular sub-goals.

Of these strategies, modeling, coaching, scaffolding and exploration are initiated by the supervisor. Articulation and reflection begin with the supervisee, but all involve a dialogue and the shifting of roles as the learner becomes more adept and more of a junior colleague. All these forms of knowledge and instructional strategies were evident in the doctoral candidature discussed and examples of such will be presented below. We understood our shared experience as a learning journey. There are twists and turns in any journey but, it could be argued, the thesis by publication brings particular hurdles, detours and crossroads. Given that the doctoral journey we undertook was for both of us uncharted territory we decided to conduct an autophenomenographical study of our experiences in our different roles and present this as a research paper that may offer guidelines for others contemplating such a pathway.

\section{Methodological Approach}

Autoethnography is a rigorous qualitative phenomenological methodology that promotes selfreflection (Chang, 2008; Duncan, 2004; Ellis, 2009; Ellis \& Bochner, 2000; Mallet, 2011; Nash, 2004). This research approach "can radically alter an individual's perception of the past, inform their present and reshape their future if they are aware and open to the transformative effects" (Custer, 2014, p. 2). Autoethnographers combine autobiography and ethnography, and seek to describe and analyse systematically personal experience in order to explore cultural experience (Ellis, Adams, \& Bochner, 2011; Morse, 1994; Van Maanen, 1988, 2006). Antikainen, Houtsonen, Houtelin, \& Kauppila (1996) emphasise the importance of autobiographical awareness, a person's understandings of his or her experiences and background. This approach can be employed in a variety of disciplines and it "entails writing about oneself as a researcher-practitioner ... it is a specific form of critical enquiry that is embedded in theory and practice" (Mcllveen, 2008, p. 14). Autoethnographers frame their understanding of their own personal and subjective 'truth' within cultural contexts (Custer, 2014; McIlveen, 2008). Autoethnographers may approach their self-analysis as either ethnography or phenomenology. In taking a phenomenological stance, if the researcher "were to study a phenomenon rather than a 'cultural place' it would be autophenomenographical rather than autoethnographical" (Gruppetta, 2004, p. 1). Autophenomenography is thus an offshoot of autoethnography and is an autobiographical genre in which the phenomenological researcher is both researcher and participant in her/his study of a particular phenomenon, subjecting her/his own lived experience to sustained and rigorous phenomenological analysis (Al- 
len-Collinson, 2011). In constructing this Allen-Collinson (2012, p. 123) uses the term "'graphy' to "delineate the research process as well as the written or other representational product of that process". The research reported here was conducted as an educational process, to improve selfknowledge and understanding, and share the experiences of the participants with others. We recognised that we were undertaking a "complex, nuanced process of sense- and meaning-making" (Smith, Flowers, \& Larkin, 2009, p. 191).

We interviewed each other on several occasions specifically for the purpose of data generation. In this process we share the roles of "author and focus of the story ... the observer and the observed, the creator and the created" (Ellis, 2009, p. 13). We used ourselves as co-participants as we investigated our individual and shared experiences (Chang, 2008). Our research is a shared autophenomenography in which we present a duality that can be understood as two sides of the same phenomenon (the supervisor and the supervisee). As the authors we are both subjects/participants and researchers, and our research strategy can be understood as a double hermeneutic approach. Smith and Osborn (2009) described this as a process of interpretative activity that involves two stages in which, "the participants are trying to make sense of their world; the researcher is trying to make sense of participants trying to make sense of their world" (p. 53). As mentioned before, in this case both the participants and researchers are the same people thus data will be presented as a "double hermeneutic spiral" (McKemmish et al. 2012, p. 1107). The value of the spiral lies in its recognition that the researcher and participants can look at the same phenomena from different perspectives (Wagstaff et al., 2014). Although uncommon, this approach is not unique. Exploring issues in teaching McMillan and Price (2010) used their dual autoethnographies and Learmonth and Humphreys (2012) explored issues of contemporary academic identity similarly employing dual autoethnography. Each of these studies presented the experiences of the author researchers as the objects of research. Similarly Carillo and Baguley (2011) exchanged, reviewed and co-constructed their shared narratives about transition from school teacher to university lecturer. This current study used interviews as a method of data generation. According to Chang (2008) interviews are useful for stimulating memory, filling gaps in information, validating personal data, and to acquire other peoples' perspectives on us. Confirming this, Tenni, Smyth, \& Boucher $(2003$, p. 2) pointed out that "research questions pertaining to one's own professional practice or personal experience clearly require the researcher to study themselves" to explore the reasons behind such professional practice.

To gather "personal memory data, self-observational and self-reflective data" both participants prepared semi-structured interview questions (Chang, 2008, p. 10) and, having agreed on a master list of questions, we both wrote about particular events that encapsulated our understandings before we spoke to each other on this matter. For example, we both wrote about the day we agreed that Rohan could change from a 'traditional' thesis to a thesis by publication. Van Maanen (1988) termed such self-narratives as confessional tales. Chang (2008) pointed out that "studying and writing of self narratives is an extremely valuable activity in understanding self and others connected to self' (p. 33). Such a process of recall and self-interrogation might equate to an internal dialogue. Having devised questions and written reflectively, we interviewed each other in a semistructured conversational manner. The interviews were recorded electronically and transcribed for analysis using Interpretative Phenomenological Analysis (IPA) that we considered the most suitable approach to analysing our lived experiences (Smith \& Osborn, 2009; Wagstaff et al., 2014). IPA is a research approach that has been informed by concepts of phenomenology, hermeneutics and ideography. Smith et al. (2009) explain that in line with its phenomenological underpinning IPA attempts to understand how participants make sense of their personal and social world but recognizes that this involves a process of interpretation by the researcher (Eatough \& Smith, 2006; Reid, Flowers, \& Larkin, 2005; Shaw, 2001; Smith, 2004; Smith et al., 2009). We independently read and re-read our narratives and the interview transcripts. Before conferring, both authors noted emergent themes (Smith \& Osborn, 2009). Van Manen (2006) explains that once 
identified by the researcher(s) themes can become objects of reflection in follow-up hermeneutic conversations between the researcher and interviewee (or in this case between the two researcher participants). Participant feedback or 'member checking' is a key feature of phenomenology (Bradbury-Jones et al., 2010). In this study member checking was integral to the analytic process and developed into a deep reflexive process that continued after the initial thematic analysis into the writing up of the research. From the emergent themes hypothetical groupings are generated that are then prioritised to form overarching themes that are reported thematically illustrated by direct quotations from the transcripts (Larkin, Watts, \& Clifton, 2006; Smith \& Osborn, 2009).

One of the criteria for estimating fairness in research processes is that there is no imbalance of power between the participants. Aguinis et al. (1996) point out that students are more likely to be successful if their relationship with their supervisor is founded on expert rather than coercive power. We decided to undertake this study after Rohan's successful completion of his thesis by which time we were "equally skilled bargainers" (Lincoln \& Guba, 1986, p. 79). Although we brought different perspectives to our shared endeavour, we were careful to explicate our thinking to each other. To extend to the reader the ability to determine the credibility and trustworthiness of our description of our experiences we have gathered data that will be presented as a blend of both voices, describing different stages in the candidature and exploring the overarching themes: Logistics, Cognitive Apprenticeship in action, and Building Trust. It should be noted that we have decided that these are the most important themes but many other issues were touched on during our conversations.

\section{The Context}

In Australia it has been the tradition that doctoral awards were mainly a single cohesive written thesis "reporting the results of a three to four year research program. An oral defence of the thesis is only available at a few Australian universities" (Mullins \& Kiley, 2002, p. 369). Until recently the submission of a thesis by publication has only been available to academic staff members of universities. In some Australian universities a thesis by publication can be undertaken by all doctoral (PhD) and Master of Philosophy (MPhil) candidates. Such theses include academic papers that have been published, accepted and/or prepared for publication. The exact requirements vary from one institution to another although globally there is a general understanding that a thesis by publication will include at least three journal articles in peer-refereed journals compiled for examination with a framing exegesis that "gives an account of the collection, the research that informed the production of the articles, and the 'doctoralness' of the body of work" (Lee, 2010, pp. 12-13). In 2013 Rohan successfully completed a $\mathrm{PhD}$ by publication taking two years and eight months (Nethsinghe, 2013a). The thesis, entitled Attaining proximal simulation in multicultural music education, explored multicultural musicking practices and contained seven articles; three were published by the time of submission, one was accepted for publication and the remainder has been published since that time (Nethsinghe, 2011, 2012a, 2012c, 2012d, 2013b, 2013c, 2015). The term 'musicking' was coined by Small $(1998$, p. 9) who argued that the word 'music' should be considered a verb as to music is "to take part, in any capacity, in a musical performance, whether by performing, by listening, by rehearsing or practicing, by providing material for performance ... or by dancing". An earlier article was included as an appendix to provide contextualising data (Nethsinghe, 2012b) as it could not be included as it had been written and published before the commencement of candidature. Rohan explained that, "each article was to be the centre of a chapter. The chapters were preceded and succeeded by framing papers to introduce the research field, contentions and underpinning philosophy". The international examiners were receptive and intrigued by the format. The doctoral thesis was considered by one of the examiners to be a substantive scholarly work that provided a "smooth-sailing read of a critical and timely issue". Jane has continued to supervise doctoral students with increasing numbers electing the 
thesis by publication format. The university guidelines have now changed with their being less insistence on the actual publication.

In 2010 the guidelines for a thesis by publication were comparatively vague. The thesis must reflect a sustained and cohesive theme, and framing papers were usually required. Whether the papers had to be published or only submitted varied across faculties and it was our understanding that in our faculty a minimum of four papers should be published or accepted. It was expected that the candidate be responsible for the initiation, key ideas, development and writing up of each of the included works. Overall, the material presented for examination was expected to equate with the traditional thesis format. Papers did not have to be rewritten but could be inserted in their published form. It is expected that all journals selected will be of a scholarly standard that meets the criteria as set out in the Australian Government Department of Industry, Innovation, Climate Change, Science, Research and Tertiary Education (DIICCSRTE) 2014 Higher Education Research Data Collection Specifications. To get a better idea of what was expected we sought examples of theses by publication on similar topics from other universities (Latukefu, 2010; Lebler, 2007). Jackson (2013, p. 355) commented that in Australia the "institutional guidelines in universities nationwide are inadequate for producing theses of comparable quality to conventional dissertations". We found the guidelines unhelpful. Recently the thesis by publication has been retitled a PhD thesis including Published works in which students may present "a thesis comprised in part or in full of published or unpublished papers" (Monash Institute of Graduate Research, 2015). Although Rohan's doctoral studies were undertaken under the earlier framework, the centrality of the supervisor/supervisee relationship that is the focus of this study has not changed.

\section{The Conversation}

To contextualise the data, an introduction to the authors' prior relationship is offered. Before commencing the thesis by publication, we worked together for several years. Jane was in charge of the music methodology subjects in the Graduate Diploma of Education (Secondary) and Rohan joined the class in 2008. This was a very successful year and we came to know each other well, particularly in the end-of-year original music theatre production that is an integral component of the subjects. The following year Rohan undertook an Honours degree and Jane supervised his research project. Rohan was the first recipient of the Monash University conjoined Honours PhD Scholarship from the Faculty of Education. From the beginning Jane encouraged Rohan to publish his research and he published three refereed journal articles from his initial Honours study. This was an important precursor to the thesis by publication and is a common strategy adopted by many research mentors who "emphasise the importance of considering a publication plan as part of project design" (Green \& Bowden, 2010, p. 121).

\section{The Decision to Undertake the Thesis by Publication}

In a mentoring relationship trust is built over time (Leck \& Orser, 2013). The development of a trusting rapport was pivotal in the decision to undertake the thesis by publication. Ultimately supervisors need to be adaptable and engender confidence in their postgraduate students (Mullins \& Kiley, 2002). Adaptability is exemplified here by our conversation about making the decision to undertake the thesis by publication. We both expected that Rohan would proceed to a doctorate he asked Jane if she would supervise his doctorate at their first meeting. Initially the degree was to be undertaken in the more usual 'traditional' seven or eight chapter format. As in many doctoral programs, students enrolled in Higher Degree Research (HDR) courses are considered to be probationary candidates until they have successfully completed a Confirmation of Candidature which involves defending their research project.

After successful confirmation of candidature, Rohan asked if he could do the thesis by publication. Initially Jane was resistant as the following exchange demonstrates: 
Rohan: Why did you allow me to use this format?

Jane: Well the first time as you remember I said 'no'. The second time I said 'no'. And then the third time you came armed with about three pages of reasons why you should be allowed to try a doctorate by publication. Can you recall what you said?

Rohan: Even before I started my $\mathrm{PhD}$ (during my Honours studies) I attended two seminars/workshops presented by the Faculties of Engineering, Health and Nursing about Thesis by Publication. At this time in the Faculty of Education HDR, students were not allowed to present a thesis by publication. Attending these seminars I understood that this would be the most suitable approach for me, as I wanted to become an academic and to build a track record of publishing, presenting, and accumulating research funding. Most importantly as an experienced multicultural musician, artist and teacher, I wanted my voice to be heard and I thought that this was the best option for me, to publish my work and establish myself. Fortunately in 2010, the year I commenced my doctoral candidature, the Faculty of Education introduced Thesis by publication for HDR students. My candidature was confirmed after eight months. It took me those first eight months and three attempts to convince you that Thesis by Publications was the best way for me.

Jane added that she had a further reason for agreeing:

I knew that you wanted to become an academic, and having a track record of publication is a very valuable thing. The second thing was that you were going to be writing and publishing from the research as you went along, whether or not you did the classic version of the thesis. So I finally thought that it seemed a little unreasonable to suggest that you then write the same set of data twice in both thesis writing style and journal writing style.

Having made the decision there were a two logistical concerns that had to be dealt with immediately. These were the preparation and submission of articles for publication and having a fallback position in mind if the articles were not accepted or the review process took too long to be accommodated within the time frame of a doctorate.

\section{Logistics: Timing, Failsafe, and Examination}

The drive to submit articles and the potential time that journals' review processes can take means that the conventional order of planning, theorising, reading the literature, and then beginning data collection is altered. From our experience, few journals in our field will accept an article that does not contain original data from a novice writer. Knight and Steinbach (2008) noted that manuscripts that deal with theoretical thinking are less likely to be published. However Rohan did submit an article that explored theoretical concepts which was published. We did not make the decision to complete the thesis by publication until after confirmation. With hindsight it might have been easier to make this decision earlier. Jane explained, "I now think the earlier the decision is made the better. We still had enough time for you to prepare the journal articles and submit them to journals and for us to then settle in to the waiting for reviews to come back which can be very lengthy. That is part of the risk in doing a thesis by publication". If a paper received a positive review, we still needed to make changes to the text and prepare the response to the reviewers which added to the overall time from submission to publication (Robins \& Kanowski, 2008). Jane was effectively working as a 'publication broker' who modelled the explication and mediation of the reviewers' comments (Kamler, 2010). While waiting for journal responses, Rohan used this time for further theorising, reading and planning. He described that during this time he "conducted literature reviews, library research, and organised the next stages of my research project because as a phenomenologist I am aware that we must remain open to the unexpected 
finding which proved to be the case". As well, Rohan attended conferences and presented his findings to experts in his field to refine his writing and enrich his research.

We discussed a range of strategies involved in submitting journal articles as the following exchange demonstrates:

Rohan: I still remember you wanted me to submit my first articles to top ranked journals.

Jane: I use the same strategies with you that I use with my own publications - I submit to the highest quality appropriate journal possible. They may reject it, which is OK, particularly if they do so with useful critique so I can modify the paper and enhance my writing. The paper can then be sent to another journal.

Rohan: One of the two papers that I first wrote and submitted to a top ranked journal got rejected.

Jane: Yes, one article got in with revision and the other one was rejected but you received good feedback. Both articles were modified. The rejected one was revised considerably and then sent to a different journal where it was accepted.

Klinger, Scanlon, \& Pressley (2005, p. 16) agree that, "[e]ven if your manuscript is not accepted, one reason to favour the best journals is that they tend to provide feedback of the highest quality, which can be quite helpful". We also discussed the submission and review process at length so that when an article was criticised or rejected, Rohan understood that this could be a very positive experience and ultimately improve the quality of his work. Lee $(2010$, p. 18$)$ offers a list of essential planning elements relating to the production of articles that included "researching and selecting journals to target; ... responding to reviewers, [and] resubmitting the article for publication". For us, it was paramount that we design a research project that as "amenable to progressive publication as discrete articles" (Robins \& Kanowski, 2008, p. 20).

As all researchers are aware, some journals can take a very long time to review articles (Knight \& Steinbach, 2008). Consequently we were selective about where we sent articles, using those that Jane knew to be timelier in responding. She explained that, "I have had some articles where you wait well over a year for reviewers' comments and that is just untenable within a thesis by publication". We decided that it was worth writing to the editor prior to submission. Rohan adopted this as his usual practice. He would send abstracts to journals and enquire if his article was suitable for the targeted journal and ask how long it might take to complete the publication process if accepted. Fairly often Rohan received a sympathetic response where an editor offered to be expeditious which was appreciated.

From the outset, we were very aware that it might not be possible to have enough articles accepted or published within the time frame. For this reason we discussed having a fallback plan whereby we could convert the research into a more conventional format. We were aware of the element of risk at all times:

Jane: One of the major problems with thesis by publication is what do you do if the journal articles are not forthcoming? It is a gamble where you think to yourself "is it worth the effort and the time to write these journal articles, send them off then to wait for three months" which is usually the minimum time to get a reviewer's response and then depending on what you have to do to improve your article, respond to that.

Rohan: Yes, you have to have a backup plan if things go wrong.

Jane: Absolutely. I always discuss an alternative plan with all the people I supervise. 
For Rohan's thesis, the failsafe was to convert the articles into a chaptered thesis format, which would have worked just as well.

The final logistical issue that we discussed as unique to a thesis by publication concerned the selection of examiners, which can be a complex undertaking (Francis, Mills, Chapman, \& Birks, 2009). Jane discusses possible examiners with all candidates before she contacts examiners to see if they are available and interested. Normally she seeks someone who is expert, conscientious, fair, and not driven by a sense of his or her own self-importance. Examiners of conventional theses believe that they are responsible for making an independent judgment about the work (Mullins \& Kiley, 2002). We were worried that some examiners might be concerned that, as Rohan's papers had already been reviewed and published internationally, there was less room for their personal judgment. In a thesis by publication, examiners focus on the quality, cohesion and rigour of the framing exegesis and conclusions. Submitting a doctorate by publication did not guarantee that examiners would be assured as the quality of the thesis (Robins \& Kanowski, 2008). Examiners who acknowledged the influence of publications that accompany traditional theses varied in how they were affected. Some saw publications as a confirmation of ability; others thought it could lighten the examiner's load as the decision had already been made that the candidate's work was worthy of publication in a peer reviewed journal (Mullins \& Kiley, 2002). For Rohan's research, prospective examiners were approached and the nature of the thesis was explained. Both examiners were comfortable with examining a thesis by publication.

\section{Cognitive Apprenticeship in Action}

With hindsight, Rohan and Jane recognise that all elements of the cognitive apprenticeship model were present in their ongoing exchanges and relationship. Of these modelling, scaffolding, coaching, and fading seemed the most significant. Surrounding all these activities was the acclimatisation and socialisation of the apprentice into the academic world that he sought to enter, the first of which was the acquisition of academic English language that is considered essential (Duff, 2010, p. 174). As will be evident, trust was pivotal to this process.

Modelling involves the student observing the expert as she carries out a task. By doing so, the apprentice can develop a conceptual model of the requisite processes. Modeling occurred in a number of ways during Rohan's candidature but as he was very much concerned with article preparation and the acquisition of academic language, we will first describe this. In shaping and refining articles for publication, initially Rohan observed as Jane made changes to his first drafts. He preferred to observe rather than have Jane return corrected texts amended in his absence. Jane continually explained how she went about the process and why she made the decisions that she did. For example, Rohan recalled that Jane stressed that an article needed to flow and themes needed to be carefully sequenced so that the reader would be led through the story that he wished to unfold. Jane explained other strategies such as reading the paper out loud which made repetitions very easy to identify (particularly for musicians). Rohan also pointed out that he learnt a lot when he watched Jane give papers at conferences. Initially his own presentations were modelled on Jane's that used a PowerPoint presentation with a clear sequence of events, not too many words on each slide as they distract the audience, and usually included powerful images. Although it is common practice in a doctorate by publication for the supervisor to be a co-author on some of the papers (Francis et al., 2009) we did not follow this practice.

Scaffolding is a process in which the expert helps the apprentice accomplish a task. Again, as writing and publishing scholarly articles in quality, peer reviewed publications is quintessential to academic life, after modelling, Jane worked with Rohan to scaffold his writing. Rohan recalled that one of the first articles he wrote had to be almost completely re-written as the journal considered his voice too passive. He explained that, 
As I learnt during the candidature there are many different writing styles in academia. To become an academic with a good publishing track record one must acquire the art of writing for academic publications. Different journals have different styles depending on the discipline area, journal style, and the country of publishing. In my experience, compared to journals published in the UK, American journals prefer a more relaxed approach allowing the use of first person in case studies and preferring simple grammar that avoids passive voice.

We discussed the preparation of a 'master' article that could be modified to match different journal styles until a successful publication had been attained. Some of these variations were initially hard for Rohan to comprehend, for example one important journal in music education research prefers author family names in the references to be in capital letters for no discernable reason. More than cosmetic changes Rohan also recognised that

there are different journals dedicated to different methodological approaches. When you submit articles for these journals it is vital to use their preferred methodological approaches and use appropriate academic language accordingly.

Rohan explained that his doctorate allowed him to purposely use different methodologies for different papers to broaden his research skills and explained that, "I employed historical research, library research, autoethnography, case study, online survey and phenomenology including IPA. I could learn different research methodologies that I see as another important advantage of undertaking a thesis by publication." Ultimately Rohan has become skilled at recognising different styles, using a range of methodological approaches and is able to analyse what is required and prepare articles accordingly. Occasionally he returns to Jane for advice but this is becoming increasingly less common as he has acquired mastery of the domain. Rohan added that he recognised that it was additionally challenging for someone who comes from a multilingual background to write in academic English. Jane responded that he had done particularly well in mastering the genre. Duff (2010) noted that students from all backgrounds might have problems with academic discourse regardless of whether their first language is the language of the institution. Pang (1999) noted that it was only through practice and learning by doing that it was possible to acquire skills in reading, writing, listening and speaking English.

Coaching was a continual process during Rohan's candidature. As Jane monitored and managed his progress there were times when she modeled, other times when she offered encouragement and advice, occasionally suggesting new tasks and strategies, and always helping him develop his self-confidence in this new milieu. Jane told Rohan that:

Your articles evolved. As we understood a Thesis by Publications has to be divisible into sections that can turn into something the right sized for a journal article, remembering that most journals want five to seven thousand words not the normal ten thousand words you can get in a chapter. You really have to be able to compress and to focus in on the one issue. For example the online survey that you did provided considerable data that was perfectly adequate for a journal article. And then from that you had the unexpected finding that then gave rise to an additional case study which again was about the right size for another journal article.

Rohan described additional strategies that "we used for example I only wrote abstracts for conferences (before preparing a full paper) and I became quite good at writing abstracts to try my ideas". Jane described the writing of abstracts as "an art in itself" and agreed that presenting at a conference was a good way to try things out. Presenting in national and international forums was another opportunity for Rohan to review his work and formed another stepping-stone to publication. Jane added that Rohan's progressive development of his writing style was very evident across his candidature as she could see his academic writing style developing. Demonstrably, Ro- 
han became increasingly able to articulate his knowledge, understanding and skill and to reflect on how he has developed these abilities. By the end of his candidature, Rohan asserted that, "my writing has been improved a lot when I compare my initial work". As Wadee et al. (2010) point out:

Coaching is about discovering and walking different paths. It is a process, formally set up to help student researchers clarify their life purpose, values and goals, and to help them attain these goals in a creative and conscious way. Coaching is not about diagnosis or pathology. Coaching assumes the student researcher to be capable and creative (p. 51).

This statement very much described how we understood this aspect of supervision that resonates with the assertion by Kamler (2008, p. 284) that doctoral publication relies on "skilled support from knowledgeable supervisors and others who understand academic writing".

Another telling example of coaching was when Jane encouraged Rohan to write an autoethnography to introduce his research. Writing an autoethnography can be a difficult and soul-searching exercise. Jane suggested that Rohan prepare his story about being "Mr multi-everything" in that he embodied his research topic, as he is multicultural, multi-musical, multilingual, multi-faith, and multi-ethnic person. Rohan was born in Sri Lanka with a Sinhalese, Dutch, English and Portuguese cultural and linguistic heritage. He later undertook musical studies in the former USSR before eventually migrating to Australia. He speaks several languages, performs in different musical genres and comes from a rich multi-faith background (Nethsinghe, 2012). Despite all this variety Rohan found writing about himself very difficult and he continually refers to that article as "the longest one I wrote and the hardest one I wrote". Jane kept encouraging or ignoring (when she was overseas) the emails from Rohan saying he could not write his autoethnography. In reality, he could not work out how to start the paper because it felt like boasting to him. Rohan knew that Jane had confidence in his ability to complete this task. Ultimately he was running out of time, so with quite some inner struggle, he did manage to complete his autoethnography which was published internationally (Nethsinghe, 2012) much to his and Jane's satisfaction. Although research has identified that doctoral writing and publications can be a site of anxiety and struggle (Kamler, 2008), Rohan found that this was only the case for this one particular article.

As stated, Fading involves the slow but intentional removal of support, counterbalanced by the candidate's assumption of increasing responsibility. This was evident in the introduction and development of Rohan's skills as a conference presenter. Initially Rohan watched Jane give papers at a number of conferences as a form of Modelling. Subsequently we gave joint papers, taking turns to talk to the PowerPoint presentation slides we had co-constructed. Next Rohan gave his own papers with Jane in the audience as a surety and finally Jane did not need to attend even though she preferred to do so. The thesis by publication format encouraged the presentation of various sections of the research at conferences. Rohan considered such presentations as an advantage because it gave him the "opportunity to present my work to experts and academics in my field at national and international conferences and use the feedback received to develop ideas, improve research papers and plan the next stages". As Rohan's candidature progressed, so did his independence. He described using an immersion approach to acclimatize himself to the complex concepts and processes of academic research. Rohan did everything that an academic might do he wrote papers, gave presentations, marked academic work, lectured, applied for research funding, and presented symposia. Wadee et al. (2010, p. 48) advise that "[a]fter some time emerging experts need to find their own voice, make their own decisions, be prepared to take risks, extend the conventions and eventually outgrow their supervisors". 


\section{Building Trust}

Underpinning all these processes of modeling, scaffolding, coaching, and fading was trust. This had been established almost from the first moment that Jane and Rohan met. There was a mutual but unspoken understanding of trust and benefice. On the part of both there was the desire to do good, to be responsible and be reliable. We are not sure how we understood this from the outset. It was never articulated in these terms. It may have grown in that first year of teacher education. Jane remembers relying on Rohan in the musical theatre production and Rohan remembers Jane's calm, assurance and sometimes brave belief that "all would be well". She repeated this mantra to the cast, musicians and crew throughout the rehearsal process. Later Rohan stated that he doubted that the performance would be a success but he was proved wrong as Jane's faith was rewarded.

With hindsight Jane asked Rohan, "Why did you think of convincing me to supervise your thesis by publication?" Rohan replied that with his prior success:

completing a small scale piece of research for my Honours degree and publishing a number of journal articles from it, I was confident that you will be the best mentor to help me with this approach and I felt that as a supervisor you also had reliance in my abilities, such as my work ethic. I think that we had a good mutual understanding of each other's capabilities when we made the decision.

A strong work ethic and a persevering attitude are essential in a successful candidature, particularly when there is a comparatively tight timeframe as in a thesis by publication. Rohan asked Jane to explain what she thought was necessary. She replied:

I think you need a student who is conscientious, diligent and prepared to put in the hard work. With you I had a great deal of faith in your ability to get things done. Therefore I thought that this was a reasonable possibility. If you were a student that I had to chase for work, and the work did not shown a lot of effort then I would be hesitant to go for thesis by publication because it will just not get done in time.

Rohan noted that some of Jane's work ethic also contributed, as she was "keen to read everything that I wrote and always gave me constructive and detailed feedback". Jane notes that overtime the nature of this feedback changed as Rohan's writing abilities developed. Now Rohan is an independent academic and researcher but he and Jane continue to write together, undertake research together, present papers together and Jane continues to be his mentor in his new role as an academic in a university.

For Rohan this is a lifelong relationship and Wadee et al. (2010) concur that mentoring "has huge potential to become a lifelong relationship" (p. 33). In some ways, Jane is envious of Rohan because when she first began teaching in a university there was little support and no mentoring. According to Wadee et al. (2010):

Everybody needs a mentor! This may not be applicable all of the time, but throughout life, and particularly in academic life, a mentor of some sort is necessary. Most, if not all, individuals have had role models but not all have had the privilege of a personal mentor who guided them through some maze, difficulty or challenge at some time (p. 34).

To a certain extent, Jane is trying to provide Rohan with what she would have liked herself. Jane explained that as a supervisor she enacts a Pedagogy of Commitment and Responsibility that draws on social justice theory in which teachers recognize the importance of relationships between individuals (Martusewicz \& Edmundson, 2004). In an ethically responsible pedagogy there is respect and engagement between different cultures, understandings, and languages that deepens and enriches the doctoral journey. Rohan added that the commitment works both ways, "as a stu- 
dent it is also highly important to commit to the learning process especially when undertaking a thesis by publications". He found that the list of elements of commitment provided by Wadee et al. (2010) exactly matched the processes he followed during his candidature. These begin with a commitment to the mentoring relationship that involves, initially time - specifically maintaining a schedule, meeting regularly, allocating time and space for focused reflection, and completing tasks when needed (or sometimes earlier). Further the mentoring relationship requires an openness to constructive criticism, the development of ideas and often-repeated review of writing, having clear goals in mind and finding a way to achieve them. There are many further factors such as "raising issues of concern (academic and non-academic) in a timely fashion" and being "unafraid to ask for assistance" (Wadee et al., 2010, p. 43).

\section{Discussion and Conclusion}

Rohan and Jane have found researching together in writing this article enjoyable and fascinating. This has given us the opportunity to reflect and understand just what it was that we were doing often intuitively. Reflecting on our shared experience informs and enriches our approaches to the supervision of other students. Rohan is now an established academic beginning to supervise his own students. Much of what he has experienced now gives him a model for his own work. We continue to talk about what is important in a supervisory relationship. Grant et al. (2014, p. 57) agree that, "the most important ingredient in successful postgraduate supervision was ... building an effective professional relationship" that includes strategies in which masters assist apprentices to become masters themselves through "modeling, scaffolding, fading and coaching" (Collins et al., 1991, p. 2). In our experience, the model of cognitive apprenticeship offers a useful structure to explore teaching and learning in higher degree research. Interestingly Rohan believes that scaffolding is the most important of these strategies as it involves both modeling and coaching. Jane believes that fading is the most important as it involves observing her students becoming independent confident academics who change from being students to colleagues. Maher, Gilmore, Feldon, \& Davis (2013) argue that the efficacy of cognitive apprenticeship relies on both supervisor and supervisee making a commitment to making this work. We both feel that there was a clear and ongoing intention to facilitate this particular doctoral journey.

The logistical hurdles encountered throughout the candidature were surmounted but at all times we were very aware of the inbuilt risks in a thesis by publication. Lee $(2012$, p.13) confirms the "risky yet productive experience of undertaking a $\mathrm{PhD}$ by publication". If asked to give advice to candidates considering thesis by publication, we assert the need to decide early, be strategic in journal selection, always have a back-up plan, keep the overall frame of the topic and the methodology in mind, and work hard. Most importantly we remained cognizant of the risks. For this reason we maintained one (if not several) back-up plans. The importance of planning cannot be overstated (Francis et al., 2009). This was a frequent topic of conversation and occasionally we would make changes to both the research and the publishing schedule to allow for the unexpected findings that occurred. We found that flexibility, patience and at times a sense of humour were key strategies in dealing with all the logistical issues we encountered. With hindsight we agree that essential to the successful doctorate by publication was an open-minded flexible approach that occasionally required steady nerves. This was most evident waiting for decisions from editors about articles - should we contact the editor or should we be patient? If we are too bothersome, we might be rejected prematurely or put to the end of the queue. As we needed more than one article for the thesis, we might simultaneously be at different stages of researching, writing, submitting, and revising different papers. Rohan encapsulated this when he described this process as "a juggling act". Andreotti (2011) refers to this 'dissensus' as giving supervisors the opportunity to "to support learners in the development of their ability to hold paradoxes and not be overwhelmed by complexity, ambiguity, conflict, uncertainty, and difference" (p. 395). Underpinning all this was the trust in our relationship. 
There is remains a lack of commonality in higher education about the nature of the $\mathrm{PhD}$ by published work (Bradley, 2009, p. 331). With the increasing prevalence of doctorates by publication by student candidates and the need to disseminate their research (Kamler, 2008), exploring one successful relationship can offer insights for other supervisors and candidates. Lee (2010, p.13) argues that, "a close examination of one doctoral graduate's experience is a useful way to make visible and articulate some of the often conflicting positions taken within the field of doctoral education". We hope that our paper might inform stakeholders and impact on the learning experience of $\mathrm{PhD}$ candidates, committees, and supervisors as they work toward publishing theses. As is evident there are many aspects to the supervisory relationship. Duff (2010) identifies these as a "social, cognitive, and rhetorical process and an accomplishment, a form of enculturation, social practice, positioning, representation, and stance-taking" (p. 170). Reflective, insightful and purposeful practice is "the bedrock of being a good supervisor [and] is one of the defining attributes of being a modern academic" (Grant et al. 2014, p. 57). We argue that this is also true for the candidate who is becoming an academic. Both supervisor and supervisee must be reflective, committed to the process, be prepared to take risks, be brave, trust and respect each other at all times.

\section{References}

Andreotti, V. (2011). Actionable postcolonial theory in education. New York, NY: Palgrave Macmillan.

Aguinis, H., Lee-Suk-Jae, Nesler, M. S., Quigley, B. M., \& Tedeschi, J. T. (1996). Power bases of faculty supervisors and educational outcomes for graduate students. Journal of Higher Education, 67(3), 267297.

Allen-Collinson, J., (2011). Intention and epoché in tension: Autophenomenography, bracketing and a novel approach to researching sporting embodiment. Qualitative Research in Sport \& Exercise, 3(1), 4862.

Allen-Collinson, J. (2012). Feminist phenomenology and the woman in the running body. In I. Martínková \& J. Parry, J. (Eds.), Phenomenological approaches to sport (pp. 130-146). Abingdon, UK: Routledge.

Antikainen, A., Houtsonen, J., Huotelin, H., \& Kauppila, J. (1996), Living in a learning society: Lifehistories, identities and education. London: Falmer Press.

Bandura, A. (1997). Self-efficacy: The exercise of control. New York: Freeman.

Bibby, M. (1999). Some ethical issues in the supervision of educational research. In A. Holbrook \& S. Johnston (Eds.), Supervision of postgraduate research in education (Vol. 5, pp. 169-182). Victoria, Australia: Australian Association for Research in Education (AARE).

Bradbury-Jones, C., Irvine, F., \& Sambrook, S. (2010). Phenomenology and participant feedback: Convention or contention? Nurse Researcher, 17(2), 25-33.

Bradley, G. (2009). Publish and be Doctor-rated: The PhD by published work. Quality Assurance in Education, 17(4), 331-342.

Carillo, C., \& Baguley, M. (2011). From school teacher to university lecturer: Illuminating the journey from the classroom to the university for two arts educators. Teaching and Teacher Education, 27, 6272 .

Chang, H. (2008). Autoethnography as method. Walnut Creek, CA: Left Coast Press.

Clegg, S., \& Gall, I. (1998). The Discourse of Research Degrees Supervision: a case study of supervisor training. Higher Education Research \& Development, 17(2), 323-332.

Collins, A., Brown, J. S., \& Holum, A. (1991). Cognitive apprenticeship: Making thinking visible. American Educator, Winter, 1-18. Retrieved from http://www.21learn.org/arch/articles/brown_seely.html 
Collins, A., Brown, J. S., \& Newman, S. E. (1989). Cognitive apprenticeship: Teaching the crafts of reading, writing, and mathematics. In L. B. Resnick (Ed.), Knowing, learning, and instruction: Essays in honor of Robert Glaser (pp. 453-494). Hillsdale, NJ: Lawrence Erlbaum Associates.

Custer, D. (2014). Autoethnography as a transformative research method. The Qualitative Report, 19(21), $1-13$.

Davies, R. E., \& Rolfe, G. (2009). PhD by publication: A prospective as well as retrospective award? Some subversive thoughts. Nurse Education Today, 29(2009), 590-594.

Duff, P. A. (2010). Language socialization into academic discourse communities. Annual Review of Applied Linguistics, 30, 169-192.

Duncan, M. (2004). Autoethnography: Critical appreciation of an emerging art. International Journal of Qualitative Methods, 3(4), 28-39.

Eatough, V., \& Smith, J. A. (2006). 'I was like a wild wild person': Understanding feelings of anger using interpretative phenomenological analysis.' British Journal of Psychology, 97, 483-498.

Ellis, C. (2009). Revision. Autoethnographic reflections on life and work. Walnut Creek, CA: Left Coast Press.

Ellis, C., Adams, T. E., \& Bochner, P. (2011). Autoethnography: An overview. Forum: Qualitative Social Research, 12(1). Retrieved from http://www.qualitativeresearch.net/index.php/fqs/article/view/1589/3095

Ellis, C., \& Bochner, A. P. (2000). Autoethnography, personal narrative, reflexivity: Researcher as subject. In N. K. Denzin \& Y. S. Lincoln (Eds.), Handbook of qualitative research (pp. 733-768). Thousand Oaks, CA: Sage.

Erdem, F., \& Aytemur, J. O. (2008). Mentoring - A relationship based on trust: Qualitative research. Public Personnel Management, 37(1), 55-65.

Francis, K., Mills, J., Chapman, Y., \& Birks, M. (2009). Doctoral dissertations by publication: Building scholarly capacity whilst advancing new knowledge in the discipline of nursing. International Journal of Doctoral Studies, 4, 97-106. Retrieved from http://ijds.org/Volume4/IJDSv4p097106Francis269.pdf

Grant, K., Hackney, R., \& Edgar, D. (2014). Postgraduate research supervision: An 'agreed' conceptual view of good practice through derived metaphors. International Journal of Doctoral Studies, 9, 43-60. Retrieved from http://ijds.org/Volume9/IJDSv9p043-060Grant0403.pdf

Green, P., \& Bowden, J. A. (2010). Writing for publication. In R. H. Cantwell \& J. J. Scevak (Eds.), An academic life: A handbook for new academics (pp. 120-138). Camberwell, VIC: Australian Council for Educational Research.

Gruppetta, M. (2004) Autophenomenography? Alternative uses of autobiographically based research. In P. L. Jeffery (Ed.) Association for Active Researchers in Education (AARE) Conference Paper Abstracts - 2004. Sydney: AARE. Retrieved from: http://www.aare.edu.au/04pap/gru04228.pdf

Holbrook, A., \& Johnston, S. (1999). The many facets of research supervision in education. In A. Holbrook \& S. Johnston (Eds.), Supervision of postgraduate research in education, (Vol. 5, pp. 17-31). Victoria, Australia: Australian Association for Research in Education (AARE).

Jackson, D. (2013). Completing a PhD by publication: A review of Australian policy and implications for practice. Higher Education Research and Development, 32(3), 355-368.

Johnston, S. (1999). Postgraduate supervision in education: An overview of the literature. In A. Holbrook \& S. Johnston (Eds.), Supervision of postgraduate research in education, (Vol. 5, pp. 3-14). Victoria, Australia: Australian Association for Research in Education (AARE).

Kamler, B. (2008). Rethinking doctoral publication practices: writing from and beyond the thesis. Studies in Higher Education, 33(3), 283-294. 
Kamler, B. (2010). Revise and resubmit: The role of publication brokers. In C. Aitchison, B. Kamler \& A. Lee (Eds), Publishing pedagogies for the doctorate and beyond (pp. 64-82). Abingdon, UK:

Routledge.

Klinger, J. K., Scanlon, D., \& Pressley, M. (2005). How to publish in scholarly journals. Educational Researcher, 34(8), 14-20.

Knight, L. V., \& Steinbach, T. A. (2008). Selecting an appropriate publication outlet: A comprehensive model of journal selection criteria for researchers in a broad range of academic disciplines. International Journal of Doctoral Studies, 3, 59-79. Retrieved from http://www.ijds.org/Volume3/IJDSv3p059-079Knight84.pdf

Larkin, M., Watts, S., \& Clifton, E. (2006). Giving voice and making sense in interpretative phenomenological analysis. Qualitative Research in Psychology, 3, 102-120.

Latukefu, L. (2010). The constructed voice: A socio-cultural approach to teaching and learning singing. Unpublished doctoral thesis, University of Wollongong.

Learmonth, M., \& Humphreys, M. (2012). Autoethnography and academic identity: glimpsing business school doppelgangers. Organization, 19(1), 99-117. Retrieved from http://dro.dur.ac.uk/9074/

Lebler, D. (2007). Getting smarter music: A role for reflection in self-directed music learning. Unpublished doctoral thesis, Queensland University of Technology.

Leck, J., \& Orser, B. (2013). Fostering trust in mentoring relationships: an exploratory study. Equality, Diversity and Inclusion: An International Journal, 32(4), 410-425.

Lee, A. (2010). When the article is the dissertation: Pedagogies for a PhD by publication. In C. Aitchison, B. Kamler \& A. Lee (Eds), Publishing pedagogies for the doctorate and beyond (pp. 12-29). Abingdon, UK: Routledge.

Lincoln, Y. S., \& Guba, E. G. (1986). But is it rigorous? Trustworthiness and authenticity in naturalistic evaluation. In D. D. Williams (Ed.), Naturalistic evaluation, new directions for program evaluation, No. 30 (pp. 73-84). San Francisco, CA: Jossey-Bass.

Maher, M. A., Gilmore, J. A., Feldon, D. F., \& Davis, T. E. (2013). Cognitive apprenticeship and the supervision of science and engineering research assistants. Journal of Research Practice, 9(2), Article M5. Retrieved from http://jrp.icaap.org/index.php/jrp/article/view/354/311

Mallet, D. (2011). Walking a mile in their shoes: Non-native English speakers' difficulties in English language mathematics classrooms. Journal of Learning Design, 4(3), 28-34.

Martusewicz, R., \& Edmundsen, J. (2004). Social foundations as pedagogies of responsibility and ecoethical commitment. In D. Butin (Ed.), Teaching context: A primer for the social foundations of education classroom (pp. 71-91). Mahwah, NJ: Lawrence Elrbaum Publishers.

Mayer, R. C., Davis, J. H., \& Schoorman, F. D. (1995). An integrative model of organizational trust. Academy of Management Review, 20(3), 709-734.

McIlveen, P. (2008). Autoethnography as a method for reflexive research and practice in vocational psychology. Australian Journal of Career Development, 17(2), 13-20.

McMillan, P., \& Price, M. (2010). Through the looking glass: Our autoethnographic journey through research mind-fields. Qualitative Inquiry, 16(2), 140-147.

McKemmish, S., Burstein, F., Manaszewicz, R., Fisher, J., \& Evans, J. (2012). Inclusive research design. Information, Communication \& Society, 15(7), 1106-1135.

Melin Emilsson, U., \& Johnsson, E. (2007). Supervision of supervisors: On developing supervision in postgraduate education. Higher Education Research \& Development, 26(2), 163-179.

Morse, J. M. (1994). Designing funded qualitative research. In N.K. Denzin \& Y.S. Lincoln (Eds.), Handbook of qualitative research (pp. 220-235). Thousand Oaks, CA: Sage. 
Mullins, G., \& Kiley, M. (2002). 'It's a PhD, not a Nobel Prize': How experienced examiners assess research theses. Studies in Higher Education, 27(4), 369-386.

Nash, R. J. (2004). Liberating scholarly writing: The power of personal narrative. New York: Teachers College.

Nethsinghe, R. (2011). Teacher as an artist vs artist as a teacher: Tensions between artists and teachers that affect multicultural music teaching. Music Education Research and Innovation, 14(1), 15-22.

Nethsinghe, R. (2012a). A snapshot: Multicultural music teaching in schools in Victoria, Australia portrayed by school teachers. Australian Journal of Music Education, 2012(1), 57-70.

Nethsinghe, R. (2012b). Finding balance in a mix of culture: appreciation of diversity through multicultural music education. International Journal of Music Education, 30(4), 382-396.

Nethsinghe, R. (2012c). The influence of informal music education in teacher formation: An autoethnography. The Qualitative Research Journal, 17(49), 1-16.

Nethsinghe, R. (2012d). The influence of informal music education in teacher formation: An autoethnography. The Qualitative Report, 17(Article 98). Retrieved from http://www.nova.edu/ssss/QR/QR17/.pdf

Nethsinghe, R. (2013a). Attaining proximal simulation in multicultural music education. Unpublished $\mathrm{PhD}$ thesis, Monash University.

Nethsinghe, R. (2013b). Safeguarding musical traditions and cultural heritage: The utilisation of community music making as a recourse for cultural and social sustainability. The International Journal of Social Sustainability in Economic, Social and Cultural Context, 8(1), 29-38.

Nethsinghe, R. (2013c). The notion of authenticity in multicultural music: Approaching proximal simulation. International Journal of Multicultural Education, 15(2), 1-16.

Nethsinghe, R. (2015). A fruitful inter-contextualisation of multicultural music in a formal educational setting. The International Journal of Learner Diversity and Identities, 2(2), 21-34.

Pang, N. S-K. (1999). The plain truth is out there. In A. Holbrook \& S. Johnston (Eds.), Supervision of postgraduate research in education, (Vol. 5, pp. 157-161). Victoria, Australia: Australian Association for Research in Education (AARE).

Paré, A. (2010). Slow the presses: Concerns about premature publication. In C. Aitchison, B. Kamler \& A. Lee (Eds), Publishing pedagogies for the doctorate and beyond, (pp. 30-46). Oxford, UK: Routledge.

Park, C. (2007a). PhD quo vadis? Envisioning futures for the UK doctorate. In R. Hinchcliffe, T. Bromley \& S. Hutchinson (Eds), Skills training in research degree programmes: Politics and practice (pp. 2743). London: Open University Press.

Park, C. (2007b). Redefining the doctorate. The Higher Education Academy. Retrieved from https://www.heacademy.ac.uk/node/4274

Reid, K., Flowers, P., \& Larkin, M. (2005). Interpretative phenomenological analysis: An overview and methodological review. The Psychologist, 18, 20-23.

Ritchhart, R., Church, M., \& Morrison, K. (2011). Making thinking visible. San Francisco, CA: JosseyBanks.

Robins, L., \& Kanowski, P. (2008). PhD by publication: A student's perspective. Journal of Research Practice, 4(2). Retrieved from http://jrp.icaap.org/index.php/jrp/article/view/136/154

Sambunjak, D., Straus, S. E., \& Marusic, A. (2009). A systematic review of qualitative research on the meaning and characteristics of mentoring in academic medicine. Journal of General Internal Medicine, 25(1), 72-78.

Shaw, R. L. (2001). Why use interpretative phenomenological analysis in Health Psychology? Health Psychology Update, 10, 48-52.

Small, C. (1998). Musicking. Middletown, CT: Wesleyan University Press. 
Smith, J. A. (2004). Reflecting on the development of interpretative phenomenological analysis and its contribution to qualitative research in psychology. Qualitative Research in Psychology, 1(1), 39-54.

Smith, J.A., \& Osborn, M. (2009). Interpretative phenomenological analysis. In Jonathon A. Smith (Ed.) Qualitative psychology. A practical guide to research methods (pp. 53-80), London: Sage Publications.

Smith, J. A., Flowers, P., \& Larkin, M. (2009). Interpretative phenomenological analysis: theory, method and research. Los Angeles: SAGE.

Tenni, C., Smyth, A., \& Boucher, C. (2003). The researcher as autobiographer: Analysing data written about oneself. The Qualitative Report, 8(1). Retrieved from http://www.nova.edu/ssss/QR/QR81/tenni.html

Van Maanen, J. (1988). Tales of the field: On writing ethnography. Chicago: University of Chicago.

Van Manen, M. (2006). Researching lived experience: Human science for an action sensitive pedagogy. London, ON: The Althouse Press.

Wadee, A. A., Keane, M., Dietz, T., \& Hay, D. (2010). Effective PhD supervision, mentorship and coaching. Amsterdam: Rozenberg Publishers.

Wagstaff, C., Jeong, H., Nolan, M., Wilson, T., Tweedlie, J., Phillips, Senu, E. H., \& Holland, F. (2014). The accordion and the deep bowl of spaghetti: Eight researchers' experiences of using IPA as a methodology. The Qualitative Report, 19 (Article 47), 1-15.

Wilson, K. (2002). Quality assurance issues for a $\mathrm{PhD}$ by published work: A case study. Quality Assurance in Education, 10(2), 71-78.

Yeatman, A. (1995). Making supervision relationships accountable: graduate student logs. Australian Universities' Review, 38(2), 9-11.

\section{Biographies}

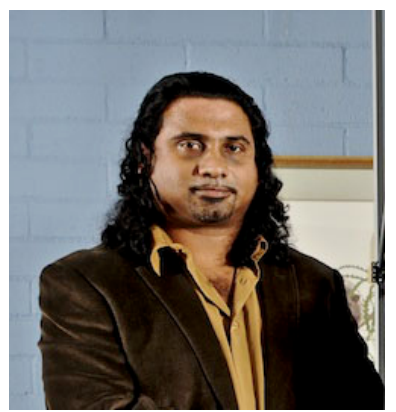

Dr Rohan Nethsinghe is a lecturer in Education at the RMIT University, School of Education and has completed music degrees in the Ukraine (Bachelor of Music in Fine Arts \& Master of Music in Fine Arts), teacher education in Australia (Honours Degree of Bachelor of Education - First Class \& Graduate Diploma in Education) including a $\mathrm{PhD}$ at the Faculty of Education, Monash University. Rohan has published in international and national refereed journals and reviews for a number of well-respected journals. He has presented papers both nationally and internationally and has also won several prestigious scholarships and awards such as the Postgraduate Publications Award (PPA); the Australian Scholarships Group (ASG) Travel Grant and the International Travel Fellowship offered by the School of Education at the RMIT University in 2014.

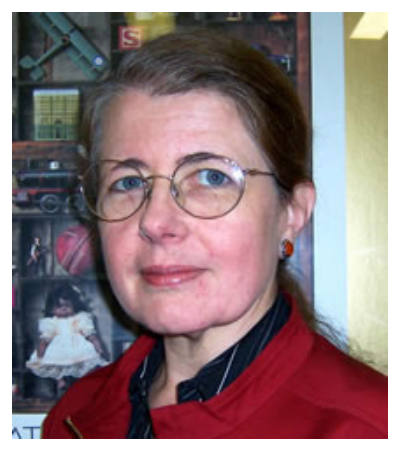

Dr Jane Southcott is an Associate Professor, Faculty of Education, Monash University, Australia. Jane researches the history of the music curriculum in Australia, America and Europe and she is also a hermeneutic phenomenologist researching community engagement with music, multicultural music education and cultural identity with a focus on positive ageing. Jane teaches in postgraduate programs and supervises many postgraduate research students. Dr Southcott is a member of the editorial boards of international and national refereed journals. She is the President of the Australian and New Zealand Association for Research in Music Education. 